POLSKA AKADEMIA NAUK ZAKEAD BADANIA SSAKOW A C VOL. V, 13 .

\title{
Mass 0ccurrence of Apodemus agrarius (Pallas, 1771) and Variations in the Number of Associated Muridae
}

\author{
Masowy pojaw Apodemus agrarius (Pallas, 1771) \\ na tle dynamiki liczebności innych myszowatych
}

In 1959 there was an increase in the numbers of Apodemus agrarius $\mathrm{P}$ a 11. greater than there had been for many years, and it seemed to us that a description of this gradation would serve a useful purpose, the more so as Polish literature on mass appearances is scanty ( $\mathrm{K} \mathrm{untze}, 1937$; $\mathrm{Simm}$ \& Skuratowicz, 1950; Skuratowicz, 1957) and does not deal with forest areas.

Research work on forest rodents in the Kampinos Forest has been carried on by the Field Station of the Institute of Ecology, Polish Academy of Sciences, at Dziekanów Leśny, since 1955 . We have made use, in the present paper, of observations conducted on three study areas I, V and VIII (Fig. 1) not widely separated from each other, situated in sections 28 and 29 of the Warsaw Woods Administration District in the Kampinos National Park ${ }^{1}$ ).

As far as habitat conditions were concerned, the study areas were similar to each other, in particular areas I and V. They are covered by forest stands of the Pineto-Quercetum association, changing over on two of the fringes to Cariceto elongate-Alnetum. This latter association was more extensively represented in area VIII.

Three species of rodent occur in considerable numbers in the study areas: Clethrionomys glareolus (S chreber, 1780) Apodemus agrarius (P a 11 as, 1771) and A. flavicollis (M el chior, 1874).Other species occur as single specimens only, and we shall not discuss them.

1) The reason for the numbers of the areas not being consecutive is that we adhered to the permanent local numbers used to distinguish the study areas. 
Area I, which is 2.5 ha in size, has been under examination since 1955 and constant observations are being continued up to the present. Results of part of the observations have been prepared and published (Andrzejewski \& Wierzbows ka, 1960; 1961).

Investigation methods in study area I consist in the capture of the rodents in live-traps set at fixed intervals of $15 \mathrm{~m}$. so as to form a network. Captures are made twice a week and the mice caught are marked with individual numbers and released (Andrzejewski \& Pielowski, 1956).

Study area V served in 1956-58 for periodical field experiments on small rodents.

In 1959 in areas V and VIII daily observations were at first made using the method applied in area I. Next total captures were made in both areas

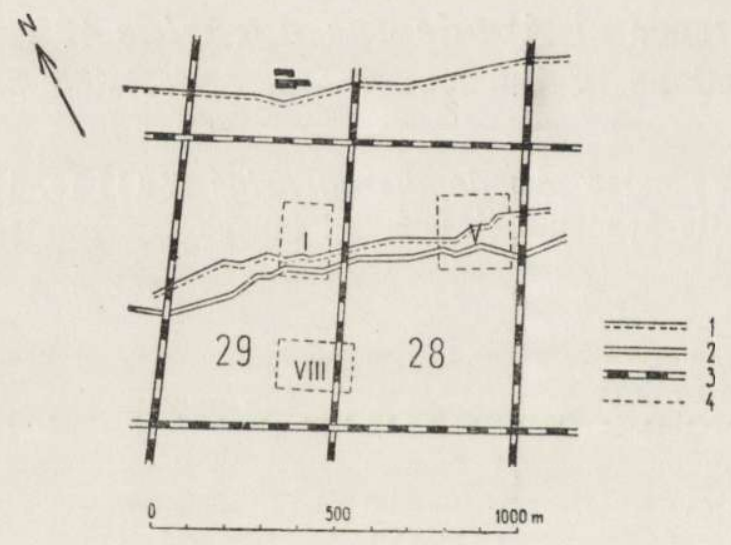

Fig. 1. Plan of study area. 1 - paths, 2 - ditch, 3 - boundary line of section, 4 - boundary of study area.

and all the rodents caught removed from them. The observation period following wholesale capture served to register the process of replenishment of the gaps caused in the rodent population by the captures.

The amount of material covered by this paper is given in table 1 .

In order to establish the variations in numbers of mice in the study areas, the density of the rodents was determined by means of the calendar of captures method (Petrusewicz \& Andrzejewski, 1961; An$\mathrm{drzejewski}$, in litt.) on the basis of the number of individuals (irrespective of the number of times a given individual was captured) living in the area at the given time, assuming that the animal existed in the study area during the period between two consecutive captures.

Variations in the numbers of all three species in area I are characterised by the annual occurrence of two main peak periods the autumm (October) which is the result of the summer repro- 
duction period, and the less distinctly expressed spring period, occurring after the early spring thaw (March) and connected with the immigration of rodents from those parts of the Kampinos Forest flooded by ground water. The spring period of minimum numbers of rodents occurs in April and May.

In order to grasp the general character of the variations in the numbers of the animals, the maximum number of rodents occurring in the study area in the various years may be compared. As, however, the absolute height of the peak is encumbered with considerable error (temporary aggregation of individuals in the study area), in order to form a better picture of the variation in numbers, calculation was made of the mean numbers from a period of

Table 1.

Number of captures made and number of individuals captured in the study areas.

\begin{tabular}{|c|c|c|c|c|c|c|c|}
\hline Area & \multicolumn{2}{|c|}{ I } & \multicolumn{2}{|c|}{ IV } & \multicolumn{3}{|c|}{ VIII } \\
\hline S1ze of area & \multicolumn{2}{|c|}{$2.5 \mathrm{ha}$} & \multicolumn{2}{|c|}{$4.7 \mathrm{ha}$} & \multicolumn{3}{|c|}{$2.5 \mathrm{ha}$} \\
\hline Study per1od & \multicolumn{2}{|c|}{ X.1955-XI. 60} & \multicolumn{2}{|c|}{ 1. IX-5.XI. 59} & 31.VIII-5. IX. 59 & \multicolumn{2}{|c|}{ 11.XI-5.XII. 59} \\
\hline No. of observations & \multicolumn{2}{|c|}{ /weekly units/ } & \multicolumn{2}{|c|}{$\begin{array}{l}67 / \text { da1ly units/ } \\
4 / \text { weekly units/ }\end{array}$} & $6 /$ da1ly units/ & \multicolumn{2}{|c|}{$25 /$ da1ly units/ } \\
\hline Specieo & \begin{tabular}{l|} 
Cap- \\
tures
\end{tabular} & $\begin{array}{l}\text { Indyv1 } \\
\text { duals }\end{array}$ & $\begin{array}{l}\text { Cap- } \\
\text { tures }\end{array}$ & $\begin{array}{l}\text { Indyv1 } \\
\text { duals }\end{array}$ & Indyviduals & $\begin{array}{l}\text { Cap- } \\
\text { tures }\end{array}$ & $\begin{array}{l}\text { Indyvi } \\
\text { duals }\end{array}$ \\
\hline A. agrarius & 3583 & 991 & 3668 & 387 & 40 & 12 & 7 \\
\hline A. Plav1collis & 1278 & 426 & 788 & 116 & 22 & 9 & 4 \\
\hline C. glareolus & 3892 & 832 & 476 & 199 & 8 & 257 & 83 \\
\hline Total & 8753 & 2249 & 4932 & 622 & 70 & 278 & 94 \\
\hline
\end{tabular}

twelve weeks, so arranged that the absolute peak occurred in the middle of this period. In similar way was stated the mean for spring minimum of animals number (Fig. 2). As the autumn peak forms the base for the winter reduction, and the spring minimum is the reproduction base for the summer rise in numbers, the transitional periods between these two phases can be passed over as obscuring the picture of significant variations in the dynamics during the yearly cycle.

In $1955-57$ the maximum density of $A$. agrarius did not vary fundamentally, neither did the numbers of $\boldsymbol{C}$. glareolus exhibit great fluctuations, despite the marked winter reduction in 1956-57. This latter species predominated numerically in all three years over $A$. agrarius. A. flavicollis, after the reduction 

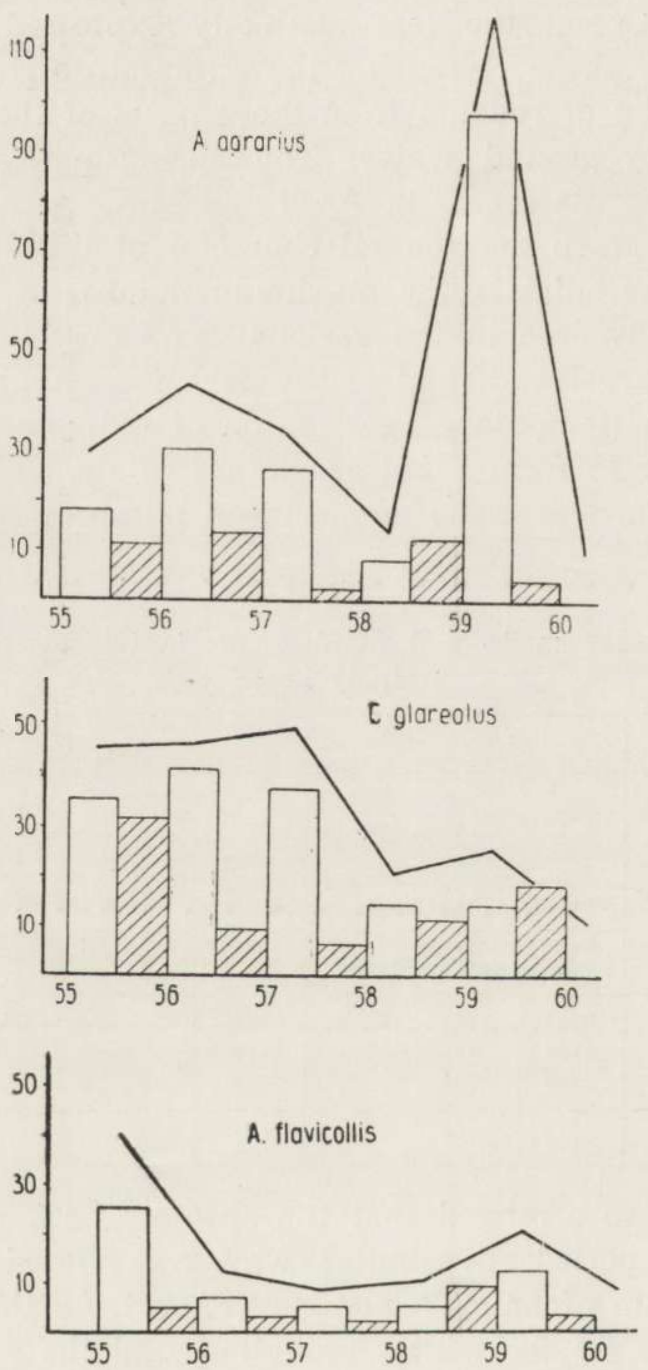

Fig. 2. Autumn maxima (continuous line) and spring and autumn mean numbers (columns) of rodents in study area $\mathrm{I}$.

from the high numerical level reached in 1955, remained in relation to the other species, on a far lower level.

In the winter of 1957-58 a marked reduction in numbers took place both with $A$. agrarius and $C$. glareolus, with a failure to restore population numbers of $C$. glareolus in the summer period of 1958, while $A$. agrarius revealed an even lower numerical state in 
the autumn of 1958 than in the spring of 1959. Similarly with $A$. flavicollis in the autumn of 1958 , the numbers were smaller than in the spring of the following year. The numbers of all the species investigated were in general very low in 1958 .

The low numbers of all three species of rodent suggest that during this time some disturbance, common to all three species, must have taken place in the elements of their ecological niche, sensu lato.

There was a rapid rise in the numbers of these rodents in the spring of 1959. As mentioned previously, it is an interesting fact that during the autumn peak of 1958 the average numbers of $A$. agrarius (and also of A. flavicollis) were lower than in the spring of 1959 (Fig. 2).

As detailed records were not kept of the size of the animals captured (as an indicator of age) it is not possible to state whether the spring increase in numbers (April-May) occurred as a result of winter and early spring reproduction of the rodents. It is, however, known that there were favourable conditions for such reproduction during that winter (B ernard, 1960; Kulicke, 1960; Z i m m er m a n n, 1960).

On the other hand, the gathering of mice from other territories in the study area during the period when the extent of the areas they settle is increased (considerable lowering in the level of ground water and drying-up of the flooded portions of the Kampinos Forest) is not very probable. This points to the correctness of the assumption that reproduction took place during the winter and early spring.

During the summer and at the beginning of the autumn in 1959 a very rapid increase in the numbers of $A$. agrarius took place, so that during the peak period the numbers were almost four times as great in relation to the mean autumn numbers in the previous years, and ten times as great in relation to the mean for autumn 1958 (Fig. 2).

This increase, compared with the variations in 1955-58 and 1960 , is distinct, despite the fact that for example, when compared with Microtus arvalis ( $\mathrm{Pallas}$, 1779), the numers of which may increase by three hundred times as many in years of mass occurrence, it is not very great ( $\mathrm{N} \mathrm{a} \mathrm{u} \mathrm{mov}, 1953)$.

It is also worthy of note that as regards numbers, $A$. agrarius in the year preceding its numerous appearance, behaved differ- 
ently from Microtus arvalis, for whom large numbers in the late autumn period and slight reduction over the winter in the year preceding mass occurrence (Naumov, 1953; Skrutowicz, 1957) are usually characteristic.

A similar course to that in study area I was followed by variations in numbers in study area $\mathrm{V}$ during the 1959 observations.

Towards the end of November a sharp, sudden fall in the population numbers of $A$. agrarius took place in both areas, numbers falling rapidly to nil. In area $\mathrm{V}$ this process was greatly hastened by the total capture operation carried out during this period (Table 2).

The reduction in population is confirmed by the fact of the very inconsiderable influx of new individuals and the lack of regeneration of the population in the total capture area V (Table 2). The ratio had clearly changed in favour of C. glareolus (Table 2)

Table 2.

Number of rodents captured in study area $\mathrm{V}$ in different years of observations.

\begin{tabular}{|l|l|c|c|c|c|}
\hline Year & Experiment & \multicolumn{2}{|c|}{ iv mber of mice } & Total \\
& & A. agrarzus & A.flavicollis & C.glareolus & \\
\hline $1956-58$ & Numerical observation & 643 & 128 & 546 & 1317 \\
\hline 1959 & Total capture & 279 & 92 & 36 & 407 \\
\hline 1959 & Regeneration of population & 8 & 4 & 42 & 54 \\
\hline
\end{tabular}

in the material entering the emptied area. This may be evidence that the reduction of $A$. agrarius had occurred in other territories outside the study areas ${ }^{1}$ ).

In area VIII captures from August 3lst to September 5th revealed the existence of $A$. agrarius in considerable preponderance over the remaining species (Table 1). Capture made from November 11 th to December 5th, however, revealed an almost complete absence of $A$. agrarius, and a large number of $C$. glareolus. This would seem to prove that the reduction in numbers of $A$. agrarius in this area occurred slightly earlier than in areas I and V.

The first symptoms of the mass appearance in process of formation of $A$. agrarius were the very rapid rise in the numbers of this species as early as from the spring onwards in 1959. During

1) Detailed analysis of the regeneration process of the artificially produced gaps in populations will form the subject of a separate paper. 
the spring and at the beginning of the summer a high index of occurrence of mice is observed, that is, the participation of new mice in the population of the study area (Fig. 3). From the spring onwards, until the moment preceding sudden reduction, a high mean of length of residence in the study areas is noted for individuals belonging to this species (Table 3 ).

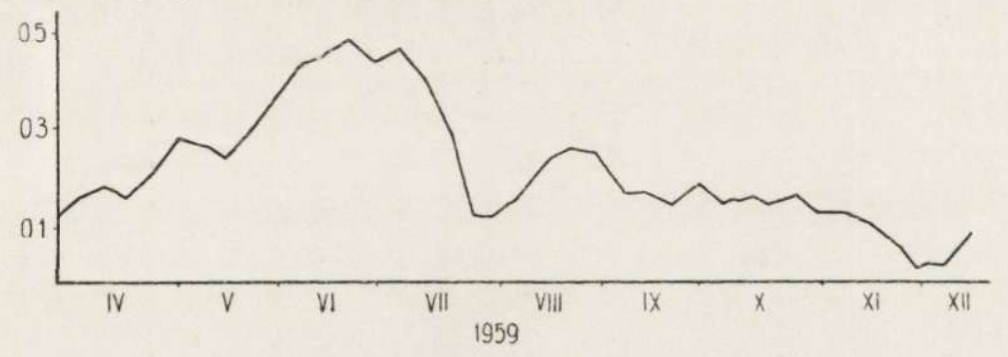

Fig. 3. Index of appearance of new mice in study area I. Value of ratio of new individuals to resident individuals placed on axis $\mathrm{X}$.

The degree of settlement of the population in 1959 was determined by means of the method, used in 1955-57 to investigate this index in area I, of comparison of the distribution of length of residence of rodents in the study area with the exponential distribution (Andrzejewski \& Wierzbowska, 1960; 1961).

Table 3.

Average length of residence (in weeks) of A. agrarius and C. glareolus in study area $I$.

\begin{tabular}{|l|c|c|}
\hline$Y_{\text {ear }}$ & A. agrar1us & C. glareolus \\
\hline $1955 / 96$ & 4.30 & 7.82 \\
\hline $1956 / 57$ & 3.25 & 4.48 \\
\hline $1957 / 58$ & 3.71 & 4.50 \\
\hline $1958 / 59$ & 8.30 & 3.46 \\
\hline
\end{tabular}

The distribution of length of residence of A. agrarius in 1959 (Fig. 4) reveals, however, a minimum but significant deviation from the exponential function. On the level of significance of 0.05 $\chi^{2}$ theoretically equals $19.675, \chi^{2}$ empirically equals 16.732 , with 11 degree of freedom. It may be considered that the deviation observed is caused by disturbance of the disappearance process connected with mass occurrence.

As the irregularity of distribution of disappearence did not permit to determine the average length of residence directly with the 
coefficient of disappearance (according to formula $\bar{t}=\frac{1}{\mathrm{p}^{1}}$ ), calculation was made in this case of the average length of residence, by adding up the individual duration of residence and dividing the result obtained by their number.

C. glareolus exhibited in 1959 agreement between the distribution of length of residence and the exponential distribution. On the level of significance 0.05 , comparing the exponential distribu-

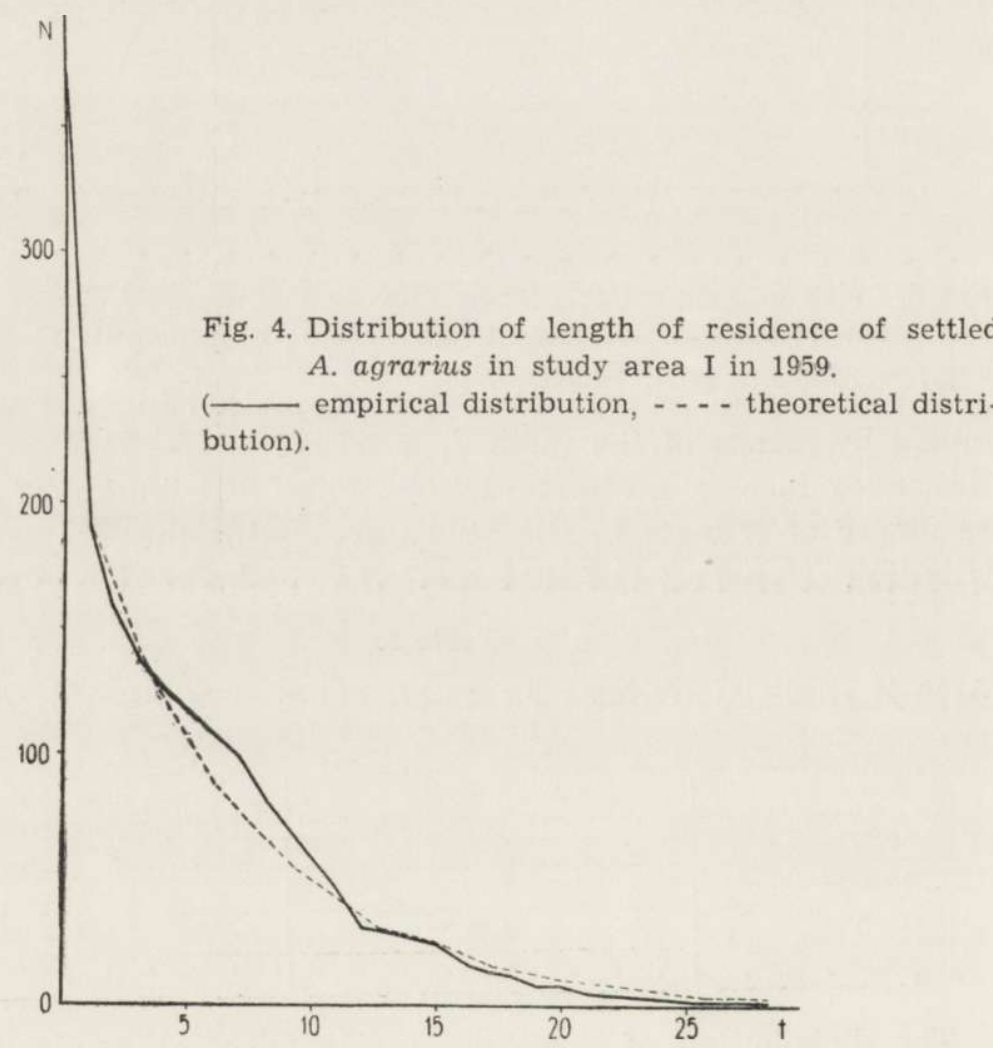

tion with the empirical distribution of length of residence, using test $\chi^{2}$, we obtain the value $\chi^{2}$ theoretically equal to 9.488 , empirical equal to 4.764 with four degrees of freedom. This made it possible to calculate the index of disappearence, the value of which was $\mathrm{P}^{1}=0.289$, and correspondig average length of residence $\bar{t}=3.46$ (Table 3 ).

The investigation method used permitted only of establishing the fact of disappearance of a given animal, without determinig 
whether it had died or had merely moved elsewhere. We cannot therefore directly distinguish between the degree of mortality and the degree of emigration. Prolongation of the average period of residence in the study area is, however, sufficient to bring about an increase in the density of the mice. As this increase takes place simultaneously in different areas (covers a wider expanse of territory) the significance of immigration must be excluded as a factor causing a rise in the numbers of the mice in the study area to the disadvantage of the remaining areas.

It must therefore be supposed that the direct causes of mass occurrence were: abundant breeding at least during the spring period, and the formation of a population structure with a high degree of residence.

On the other hand the high degree of residence might be one of the factors reducing mortality in the population.

In both the areas subjected to detailed observation (I and V) the C. glareolus population remained on a low level in 1959 (Table 2, fig. 2). It is possible that this reduction was the expression of the custing from the area of the above species by the rapidly increasing numbers of $A$. agrarius. This view is confirmed by the fact of the lower average numbers of $C$. glareolus in the autumn of 1959 than in the spring of 1960 and the low average length of residence of this species in the study areas during the peak period in numbers of A. agrarius (Fig. 2, table 3).

The results of captures given in table 2 may serve as proof of the reduction in the numbers of $C$. glareolus in area V. The specific composition of the population observed there in previous years (Table 2) rules out the possibility of this reduction being caused by habitat factors.

The possibility of $C$. glareolus being ousted by $A$. agrarius is further borne out by the fact that no autumn peak period of the numbers of $C$. glareolus occurred in 1959 in the study areas in which there was an increased number of $A$. agrarius, such as normally occurred in years with average density of rodents (1955-57), and finally, by the increase in the numbers of C. glareolus on reduction of the mass occurrence. For instance, in area I from December 2nd to March 31st 1960, 43 individuals of C. glareolus and only 3 of A. agrarius and A. flavicollis were caught. As reproduction did not seem to occur during the period of increase in the 
numbers of $C$. glareolus, therefore this increase was caused by the immigration of this species from other areas. It is possible that the ousting of $C$. glareolus consisted, amongst other things, in its occupation of areas (habitats) less suitable for A. agrarius, whence after the large numbers of the latter species had decreased, $C$. glareolus once again spread over the area.

The results of captures (Table 2) indicate the rise in numbers of $C$. glareolus during the period of regeneration of resident mice in study area $\mathrm{V}$ after the previous totally eliminating captures carried out there.

It is perhaps worth while adding that throughout the whole period of our investigations $A$. flavicollis, generally speaking, occurred as the least numerous species.

Summing up of results:

1. In 1959 a marked increase in the numbers of $A$. agrarius took place in the Kampinos National Park.

2. 1958 was a year of very low numbers for all three species of small rodents occurring in the study areas.

3. Good reproduction conditions in the spring of 1959 and the formation of a population structure with a high degree of residence and hence of reduced mortality, were direct causes of the mass occurrence of A. agrarius in 1959.

4. The period of maximum numbers was followed by a sudden reduction in the population of $A$. agrarius.

5. Mass occurrence took place with A. agrarius, while the numbers of $C$. glareolus were observed to decrease in relation to the normal figures for 1955-57, and the autumn peak of this species did not occur. On the basis of these facts and the increase in numbers of C. glareolus in the winter of 1959/60 and early spring of 1960 , the opinion may be put forward that C. glareolus was ousted by $A$. agrarius - the species in which mass occurrence took place.

\section{REFERENCES}

1. Andrzejewski, R. \& Pielowski. Z., 1956: Metoda badań ekologicznych nad drobnymi gryzoniami w warunkach leśnych $\mathrm{w}$ oparciu o wykorzystanie przynęty, znakowanie i wypuszczanie złowionych zwierząt. Ekol. Pol., B, 2, 3: 209-214. Warszawa.

2. Andrzejewski, R. \& Wierzbowska, T., 1960: On the degree of residency and migrancy in populations of small rodents. Bull. Acad. Pol. Sci., Cl. II, 8, 7: 293-300. Warszawa. 
3. Andrzewski, R. \& Wierzbowska, T., 1961: An attempt at assessing the duration of residence of small rodents in a defined forest area and the rate of interchange between individuals. Acta Theriol., 5, 12. Białowieża.

4. B e rna rd, J., 1960: Note sur la reproduction en hiver du Campagnol des champs, Microtus arvalis P a 11.. Ztschr. Säugetierkde, 25: 91-94. Berlin.

5. Kulicke, H., 1960: Wintervermehrung von Rötelmaus (Clethrionomys glareolus), Erdmaus (Microtus agresits) und Gelbhalsmaus (Apodemus flavicollis). Ztschr. Säugetierkde, 25: 89-91. Berlin.

6. Kuntze, R., 1937: Krytyczny przegląd wiadomości o szkodliwych gryzoniach, zebranych przez Stacje Ochrony Roślin w Polsce w latach 1919-1934. Roczn. Ochrony Roślin, 4, 2: 一.

7. (N a u mov, N. P.) Н а у мов, Н. П., 1953: Динамика численности обыкновенной полевки (Microtus arvalis $\mathrm{Pallas}$ ) и методы её прогнозов в средней полосе СССР. Зоол. журн. 32,2: Москва.

8. Petrusewicz, K. \& Andrzejewski, R., 1962: Natural history of a free-living population with a particular reference to grouping within the population. (in preparation).

9. Simm, K. \& Skurat owicz, W., 1950: Z badań nad masowym pojawem gryzoni polnych na Ziemiach Zachodnich w 1946-47 roku. Bad. Fizjogr. nad Polską Zach. 2: - Poznań.

10. Skuratowicz, W., 1957: Uwagi o pojawach gryzoni polnych w Polsce w latach 1945-1955. Ekol. Pol., B, 3, 1: 3-16. Warszawa.

11. Zimmermann, K., 1960: Wintervermehrung der Feldmaus (Microtus arvalis) bei Potsdam-Rehbrücke 1958/59. Ztschr. Säugetierkde, 25: 94-95. Berlin.

Polish Academy of Sciences, Institute of Ecology, Warsaw, Nowy Swiat 72.

\section{S T R E S Z C Z E N I E}

Na terenie Kampinoskiego Parku Narodowego prowadzone są przez Zakład Ekologii PAN od roku 1955 badania nad dynamiką liczebności drobnych gryzoni.

Metoda badań polega na połowach gryzoni (tabela 1) pułapkami żywołownymi na kilku hektarowych powierzchniach, znakowaniu indywidualnemu i wypuszczaniu. Na badanych terenach występują licznie trzy gatunki gryzoni: Clethrionomys glareolus (S chreber, 1780), Apodemus agrarius (P a 11 a s, 1771) i A. flavicollis (M e l chior, 1834).

Przeprowadzone obserwacje wykazaly:

Po okresie średnich ilości gryzoni w latach 1955-57, rok 1958 był na badanych terenach rokiem bardzo niskiej liczebności wszystkich 3 gatunków 
(Ryc. 2), W roku 1959 liczebność A. agrarius wzrosła czterokrotnie w stosun$\mathrm{ku}$ do średnich ilości jesiennych $\mathrm{z}$ poprzednich lat oraz 10 -krotnie w stosunku do średniej jesiennej z 1958 r. (Ryc. 2). Pod koniec listopada 1959 nastąpiła szybka redukcja ilości $A$. agrarius.

Bezpośrednimi przyczynami masowego pojawu były dobre warunki rozrodu wiosną 1959 (Ryc. 3) oraz wytworzenie struktury populacji o dużym stopniu osiadłości (Tabela 3),

Masowy pojaw opjąi gatunek A. agrarius, natomiast zaobserwowano równocześnie zaniżenie liczebności $C$. glareolus w stosunku do normy $z$ lat 1955-57oraz nie wystąpienie $u$ tego gatunku szczytu jesiennego (Ryc. 2). $\mathrm{Na}$ pcdstawie tych faktów oraz zwyżki liczebności C. glareolus zimą 1959/60 i wczesną wiosną roku 1960 (Tabela 2) można postawić hipotezę, że nornica była wypierana przez A. agrarius - gatunek objęty masowym pojawem.

BIBLIOTEKA

Instytutu Biologii Ssaków

Polskiej Akademii Nauk

$\mathrm{NrCz} .40 .2$

Państwowe Wydawnictwo Naukowe * Warszawa $1961 \mathrm{r}$. Naklad 1420 egz. Ark. wyd. 0,75. Maszynopis otrzym. 31. VII. 1961 r. Podpisano do druku 1. X. 1961 r. Druk ukończ. 15. X. 1961 r. Papier druk sat. kl. III. 80 g. Format B-1

Białostockie Zakłady Graficzne. Zam. $3384 *$ B-3 * Cena 5 zl. 